\title{
GCU
}

Glasgow Caledonian

University

University for the Common Good

\section{Re-imagining social enterprise}

Kay, Alan; Roy, Michael; Donaldson, Cam

Published in:

Social Enterprise Journal

DOI:

10.1108/SEJ-05-2016-0018

Publication date:

2016

Document Version

Author accepted manuscript

Link to publication in ResearchOnline

Citation for published version (Harvard):

Kay, A, Roy, M \& Donaldson, C 2016, 'Re-imagining social enterprise', Social Enterprise Journal, vol. 12, no. 2, pp. 217-234. https://doi.org/10.1108/SEJ-05-2016-0018

\section{General rights}

Copyright and moral rights for the publications made accessible in the public portal are retained by the authors and/or other copyright owners and it is a condition of accessing publications that users recognise and abide by the legal requirements associated with these rights.

Take down policy

If you believe that this document breaches copyright please view our takedown policy at https://edshare.gcu.ac.uk/id/eprint/5179 for details of how to contact us. 


\title{
Re-imagining social enterprise
}

\author{
Alan Kay, Michael J. Roy and Cam Donaldson \\ Yunus Centre for Social Business and Health, Glasgow Caledonian University
}

Author's Pre-publication version

To cite:

Kay A, Roy MJ and Donaldson C (2016) Re-Imagining Social Enterprise. Social Enterprise Journal 12(2). DOI: dx.doi.org/10.1108/SEJ-05-2016-0018

\begin{abstract}
Purpose: This intentionally polemical paper will re-examine what is meant by social enterprise and try to assert its role within the current economic system. It is well over a decade since John Pearce's Social Enterprise in Anytown was first published. Since then the term 'social enterprise' has been used in multiple ways by politicians, practitioners and academics - very often for their own ideological ends.

Design/methodology/approach: This paper will outline the context and challenges currently facing social enterprise both from outside and from inside the social enterprise movement. Findings: This paper re-affirms a paradigm for social enterprises through re-imagining how social enterprise should and could contribute to the creation of a fairer and more just society. Originality/value: Finally, this paper will conclude with a reflection on what Pearce argued and how the social enterprise movement has to position itself as a viable alternative way of creating goods and services based on socially responsible values.
\end{abstract}

\section{Introduction}

John Pearce (2003) begins his book, Social Enterprise in Anytown with the sentences:

'The world of social enterprise is changing with great speed. The pace has been at times breath-taking.'

This pace of change has continued, even accelerated, since the book was first published well over a decade ago. Over this time, we have seen social enterprise presented as a key player in sweeping reform of the public sector, and, alternatively, as a different way of exchanging goods and services based on shared social values. Although this rhetoric might appear to vindicate Pearce's vision for social enterprise, the reality is that this has resulted in differing configurations of 'social enterprise' and how it can contribute to the 
economy. Not all of those configurations, it will be argued, are beneficial to the social economy sector. Some may be damaging, rather than enhancing human welfare.

I first met John Pearce in 19881. From the mid-1990s to his untimely death in 2011, we worked closely together, as friends and colleagues, supporting social and community enterprise in Scotland and internationally, often under the auspices of CBS (Community Business Scotland) Network. I wrote one of the chapters of Social Enterprise in Anytown and worked closely with him in all aspects of the book's development. One of the first books to set out the scope of social enterprise within the economy, the first chapter adopts a visionary and deliberately idealised view of social enterprise and outlines how a social economy can be built within 'Anytown'. Using social enterprises and their structures to imaginatively describe a local economy based upon the aim of improving the well-being of everyone in society, he then speculates how a vibrant local economy can contribute to the development of a community - socially and economically - while at the same time being environmentally responsible. His utopian vision shows how social enterprise can be the instrument in caring for older people, providing for the education of young people and children, and how those least able to help themselves can be an integral part of a thriving local and social economy (Pearce, 2003).

The main thrust of our intentionally and unashamedly polemical article - taking our cue from Grey \& Mitev's (1995) critique of management education - is that the expansion of social enterprise, and the types of social enterprise activity we see, has been largely driven, at least in the UK, by the perceived need to reform the public sector and in particular to deliver services for citizens. This has skewed how 'social enterprise' is regarded and this, at least in our minds, is fundamentally problematic. While fully recognising that social enterprise theory has moved on considerably over the last decade, we suggest there is considerable value in returning to Pearce's basic conception as an operating definition. We will attempt to explain why Pearce's vision of Anytown has not materialised in the way that he outlined, nor on the scale that he wished by first outlining what Pearce's vision was. This is followed by an examination of how the development of social enterprise has been affected by the changing relationships between the public, private and third sector systems within the economy. This allows for consideration of a number of factors not anticipated by Pearce. In the light of these factors, Pearce's vision

\footnotetext{
${ }^{1}$ The first author, Alan Kay
} 
is then re-examined and social enterprise re-imagined as being an integral part of an economy that seeks to maximise well-being for all.

\section{Pearce's vision}

Social Enterprise in Anytown can be described as 'seminal' as Pearce charts a blueprint for our understanding and concept of social enterprise, much of which is still relevant today. He defines what is meant by social enterprise and argues that such entities should: have a primary social purpose to benefit the community or a specific beneficiary group; engage in trade - exchanging good and services; be non-profit distributing so personal financial gain is limited; hold assets 'in trust' and not sold for individual benefit; be run on democratic lines as much as possible; and be accountable to their 'constituency' and to the wider community (Pearce, 2003).

Pearce also insists on their underpinning values of co-operation, decentralisation, inclusivity, good work, environmental sustainability and being people-centred. He explains using the diagram shown in Figure 1, where social enterprise and the wider 'social economy' both fit, showing that the latter is differentiated in a spatial way within the wider economy. This diagram remains highly influential, not only in Scotland, but internationally (see, for example, Anheier \& Toepler, 2009; BALTA, 2007; Lewis \& Swinney, 2008; RIPESS, 2015,: 11), particularly in relation to policy literature relating to the place and scope of the social economy and, for this reason, the diagram requires a fuller explanation. 


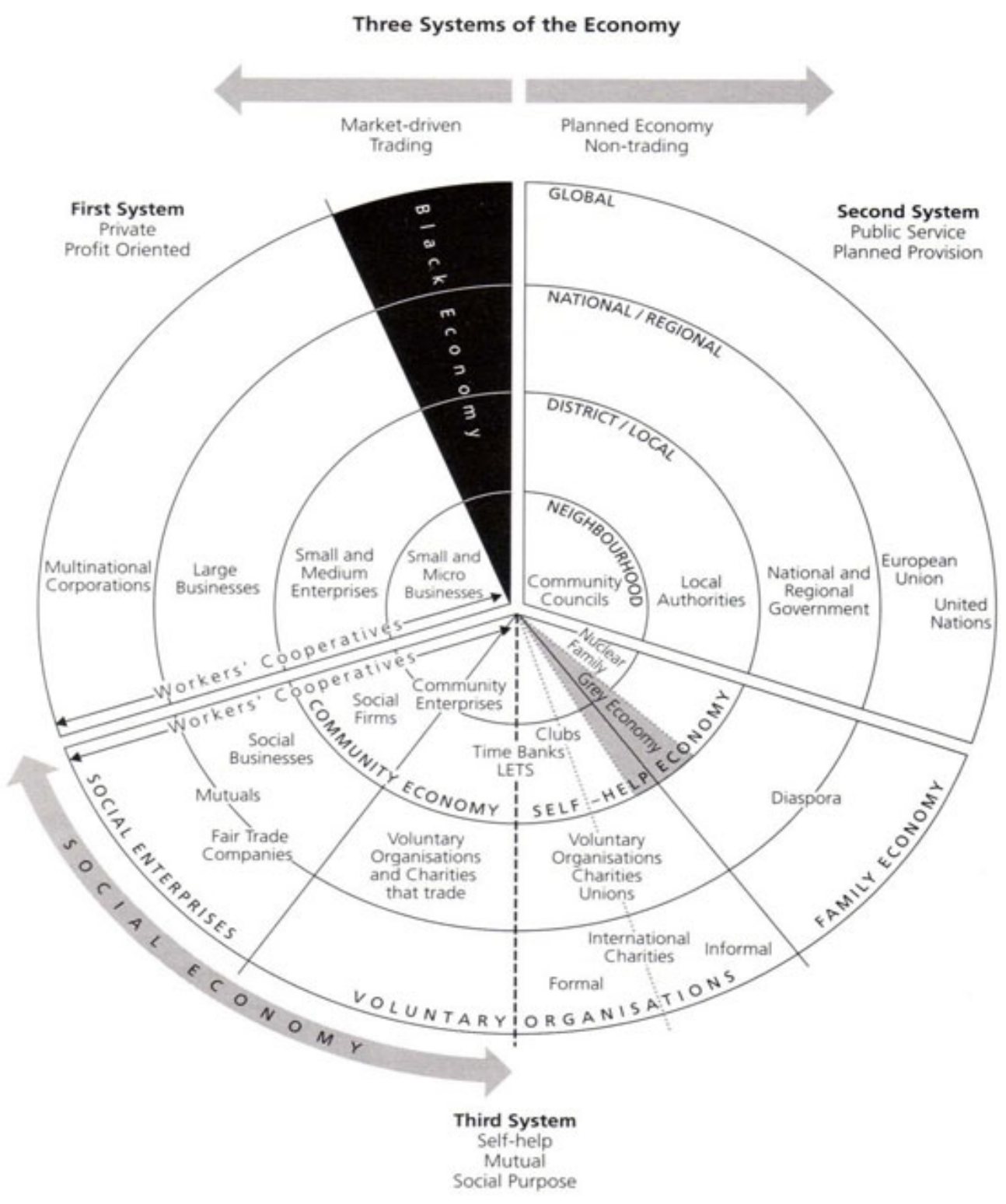

Figure 1: Three Systems of the Economy (Source - Pearce, 2003)

The three distinct systems of the economy are organised - and this is important to emphasise - in accordance with their over-riding values. The First System (or private sector) is essentially profit-driven, maximising return to private shareholders, founded on competition and celebrating individual gain (Pearce, 2003: 24). The Second System (public sector) is about re-distribution and planning within the public service based around democratic institutions (Pearce, 2003: 26). The Third System is about citizens taking collaborative action, centred on 'principles of self-help and mutuality, of caring for others and of meeting social needs rather than maximising profits' (Pearce, 2003: 26). 
The diagram can be used in a number of different ways to analyse what is now called the third sector at a local, regional, national and international level. At a local level, social enterprise often becomes 'community enterprise' where there is a commitment to the local community. Indeed, community businesses and community enterprises in Scotland in the 1980s were owned and controlled by local people and addressed the social and economic needs of people at a local level in terms of employment and services (Roy et al., 2015).

The diagram can be used to spatially define social enterprise, but its real analytical value can be gained in looking at trends in the relationships between the three systems. This is particularly useful given that the ebb and flow between the systems has changed significantly in the past two decades, especially concerning changing power structures. It is worth unpacking these structures and the associated trends between the three systems and their predominant values. For instance, governments are raising proportionally less in taxation and thus less is spent on public services. This has led to widespread outsourcing of public services, with an accompanying (but often misplaced) belief that this will reduce costs. This translates in the diagram into a shift of emphasis away from the Second System towards the First and also to the Third System. This may benefit the development of the social economy but it raises questions around accountability, scale, the quality of the service, and the capacity of Third System organisations. Essentially, are they able to cope with this trend?

Connected to this is a widely held belief that the values and principles of First System organisations (privately owned enterprises) are considered to be the unquestionable 'norm' and are seen by some to be more efficient in the delivery of public services. In some cases this may well be true, but it could also be argued that this prevailing view has also led to an undervaluing of the public sector and to the dismantling and reconfiguring of the state. Social enterprise, as part of the Third System, has been affected by this: as an alternative provider (good for expanding social enterprise) but also as part of the privatisation agenda (bad for image).

Accepting the Pearce definition and the spatial portrayal of the social economy, it can be seen that social and community enterprise has a place within the economy. However, Pearce argues that social enterprise is a distinctive way of providing goods and services - an alternative to the private and public sectors. To begin the process of illustrating how 
Pearce's vision of Social Enterprise in Anytown has not materialised in the way that he outlined or on the scale that he described, the following section will look at the changing 'landscape' surrounding social enterprise and the push and pull that it experiences from other sectors in the overall economy.

\section{The changing 'landscape' surrounding social enterprise}

The idea that the economy needs to serve society and that this purpose is intrinsically embedded in societal relations has regained considerable traction in recent years, particularly since the global financial crisis. There is a realisation that the current world economy based on neo-liberal, so-called 'free market' principles, has brought considerable benefits to some but clearly not to everyone. In fact, with its current structure, and with its implicit and often unstated principles, the world economy is causing increasing inequalities, with wealth and power becoming increasingly concentrated within, and controlled by, a small minority.

Although still very much a fringe activity in comparison to the capitalist mode of business, social enterprise in one form can be seen to represent a viable, and potentially radical, alternative to mainstream enterprise. Moreover, social enterprises can work to build and maintain 'social capital' which is described in Anytown as the "intangible 'something' that exists between individuals and organisations within a community; the connects and trusting contacts that people make while going about their daily business" (Kay, 2003: 75). The end result of social enterprise, as envisaged by Pearce, should address inequalities and injustices and provide well-being for all.

These ideas resonate with the work of Karl Polanyi $(1944,1957)$. At the same time as the emergence of social enterprise in modern industrial economies, the work of Polanyi has re-emerged as speaking directly to the reasons for the recent (and ongoing) global financial crisis and possible solutions to it. The prescient work of Polanyi and the rise of social enterprise has precipitated a need to think differently about notions such as economic growth and what it means to be an 'economic entity' in a modern society. Social enterprise has been portrayed as one such entity, but often struggles for legitimacy amongst the more conventional sectors of the economy, mainly when it tries to 'ape' the more conventional systems, rather than try to establish an alternative way of working. 
If we have learned nothing else over the last couple of decades of social enterprise scholarship, it is that the notion of social enterprise is highly complex and contested.

Pearce (2003: 50) refers to the 'radical' and 'reformist' approaches as a way of further understanding the different underpinning motives for social enterprise. Drawing on Pearce, Fitzhugh \& Stevenson (2015: 208) refer to

'...the extent to which social enterprises wanted to offer ways of changing the fabric of the current economic, political or cultural environment (radical) or alternatively focussed on improving people's lot and solving problems within the current climate (reformist) as a route to change.'

Similarly, Ridley-Duff \& Bull (2011: 103) identify two broad social enterprise 'camps' as those who 'seek to subvert the logic of the free market and change relationships between money, land and people'; and those that 'accept [free market capitalist] globalisation and use it to advance social entrepreneurial enterprises'. The first type would seem to equate to Pearce's 'radical' approach; the latter with the 'reformist' approach.

This article will refer to 'radical' and 'reformist' - recognising that they are at opposite ends of a spectrum, and that many individual social enterprises possess different aspects of both ends. These two approaches are linked to the nature of the business and the way profits are used and distributed. Although this article argues for a need for a 'radical' approach - social enterprise, rather than being just a philanthropic business, offers an alternative modus operandi - it is fully recognised that there are significant external pressures that social enterprise faces from the public and private sectors (Second and First Systems), and pressures which can arise from within the movement itself.

\section{(a) The 'pushes' from the public sector}

Governments across Europe and indeed elsewhere are intent on reducing - not increasing - their expenditure on public services. This is partly as the expected tax revenue is declining in relative terms, not least due to large multinational companies adopting increasingly sophisticated tax avoidance schemes, such as those recently exposed by the Panama Papers scandal. The rise in government interest in social enterprise, at least in the UK, can be tracked back to the New Public Management reforms started by the Conservative governments of the 1980s and 1990s, but which accelerated under Blair's Third Way (Teasdale et al., 2013; Teasdale, 2012b). There is a grave danger 
that they will be implicated (unwitting or otherwise) in an ideological agenda to further drastically reduce the size of the state. For example, the (Conservative) Chancellor of the Exchequer, George Osborne MP recently set out his target of reducing the size of the UK public sector from $46 \%$ to $36 \%$ of GDP over the next ten years, a radical and unprecedented reduction in the context of western economies; indeed 'the only bigger cuts have been the brutal shock therapies which happened in Eastern Europe after the Soviet Bloc collapsed' (Hassan, 2015). Arguably, much of the hype (Floyd, 2013b) around social enterprise and the subsequent exaggerated expectations for what social enterprise might be able to do has stemmed from a governmental need to persuade the wider public that outsourcing services does not necessarily mean privatisation (although that may be the ultimate intention), and that social benefits can result from this policy to outsource services - especially if the outsourced provider happens to be a social enterprise.

There is a continuing expectation too that social enterprise can create beneficial social change, and at the same time generate enough surplus to sustain itself and thus provide cheaper delivery of public services. In some case this may indeed be the case, but social enterprises need to be aware of the dangers and political implications of being unwittingly co-opted by the public sector to act as service providers, and not as independent organisations addressing social and community needs.

As well as losing independence, a social enterprise is subject to competitive pressures which can result in major difficulties in maintaining the quality of its social purpose and surviving financially. In time there is a danger that it will either be replaced by a private sector company or become very similar in its approach and operation to any other mainstream business. A social enterprise has to juggle its role of service provider for the public sector and at the same time has to sustain itself in a pressured commercial environment (Teasdale, 2012a). This would appear to be asking too much of social enterprises.

Extending this further, the on-going reform of the public sector with outsourcing of contracts has meant that social enterprises that started as 'radical' social enterprises when they were originally being formed are being encouraged to operate more like 'reformist' social enterprises, thus having to compromise their original values and their ways of working (see, for example, Dey \& Teasdale, 2015). In addition, some private sector businesses seeking public sector contracts may, for tactical reasons, exploit the 
label of 'social enterprise' without fulfilling many of the key characteristics and values of a social enterprise expressed by Pearce, such as in the case of Circle Health (McKee, 2011; Roy \& Hackett, 2016). The consequence of this is the more 'radical' social enterprises that want to stress their alternative credentials will lose out.

Perhaps linked to this would appear to be too much focus on social enterprise as a deliverer of social change and not enough emphasis on how a social enterprise operates with underpinning and shared values such as co-operation, collaboration, inclusiveness, and democratic decision-making structures. As well as having value in themselves, embracing and implementing such shared values could have added value in terms of the impact of social enterprise on well-being.

This mismatch of theory and practice is further compounded as governments are increasingly focusing only on the outcomes and impacts provided by social enterprise. Some have gone as far as to expect a future where the contractual payment to social enterprise is based solely on the outcomes they achieve (McHugh, et al, 2013). This approach undermines the importance of how the outcomes are achieved, and thus the wider impact of the social enterprise on community well-being. Governments are often mistaken over the potential capacity of 'radical' social enterprises, which are often local, small scale and dependent on volunteer labour working alongside paid workers. Social enterprises have often originated to address a specific social problem and often use available resources in creative ways, as primarily alternative providers of services that address only social and community needs. Thus, the more extensive potential benefits for community well-being can be missed.

\section{(b) The 'pulls' from the private sector}

There is increased understanding that free market economic and global capitalism is a system which causes widening discrepancies between rich and poor. Despite this, there is a belief that it still can be 'tweaked' and converted to be a force for addressing inequality and poverty amongst a high proportion of the world's population. This dichotomy is almost Orwellian in its thinking as the cause of the problem is then being applied to rectify the problem it originally created. Although the major social problems are caused to a significant degree by capitalism, the widely held assertion is that what is required is more capitalism but with a 'social face'. Some social enterprise advocates 
would seem to collude with this notion by down-grading the importance of their values, their priorities and the factors that make them different and distinct from private business, and instead place more emphasis on being - or becoming - increasingly 'business-like'. This is problematic, not least for upholding the values, and independence of, the third sector (as recognised, for instance, by Eikenberry \& Kluver, 2004).

The social enterprise sector meets the private sector in the area of Corporate Social Responsibility (CSR). There are undoubtedly benefits resulting from CSR as it makes businesses think about some of the social consequences of their actions. But CSR is predicated on following free market economics on the one hand and then mitigating this accumulation of profit through philanthropy. The recent increase in interest in 'B-Corps', originating from the United States, could be seen as an example of this. Indeed, the role of large corporations, though philanthropic means, can have a disproportionate influence over what social issues are tackled, and the level of priority they are afforded.

\section{(c) The 'push-me-pull-you' within the social enterprise sector}

Social enterprise has not only to resist the pressures from both the private and public sectors to shift from taking a 'reformist' approach to a 'radical' one, but also has to take account of the pressures coming from within the sector itself - especially around individualism, definitions, and its values.

\section{The rise of the individual (and competition) over the collective}

An issue that was not really tackled in-depth by Pearce, although alluded to at times, is the role of the individual 'social entrepreneur'. He recognised that since the late 1970s there has been more focus on individual action as the instrument of social change. Working together for the common good, which was a mainstay of the community business movement in Scotland in the 1980s, has been downplayed, and the idea of collective solidarity is being replaced by philanthropy. Social enterprises have been sucked into expecting 'social entrepreneurs' as individuals to instigate social change and well-being in innovative ways. As well as mirroring our argument above, about the private sector crowding out radical social enterprise, it could be argued that the social enterprise sector is losing its collective way of working.

Pearce's definition of social enterprise argues against individual gain. Extending this 'individualisation' in the social enterprise sector, there have been attempts to 'loosen' 
Pearce's definition particularly around this area of gain or returns for the social entrepreneur(s). The mainstream belief seems to be that individual financial gain is one of the main incentives for the development of a social enterprise. Often this view will emerge from an implicit ideology of self-interest, counter to the idea that the common good is the driving force behind the creation of social enterprise.

In re-imagining social enterprise, we perhaps have to recognise that we are not a series of individuals but rather part of a society. It is society that needs to change and this is best done through collective vision and understanding of social change. Connected to this individualism is the idea of competition. Pearce in his definition and in wider writings stresses co-operation and collaboration rather than competition and, through this, proposed an alternative way of running an enterprise, and indeed a sector (Pearce, 2003).

\section{The avoidance in defining social enterprise}

In definitional terms, social enterprises are at a pivotal point of their development and perhaps we are emerging from the 'pre-paradigmatic' (Nicholls, 2010) stage of field development. On the one hand social enterprises could be subsumed by the prevailing economic system and become a 'social' subset of private business (reformist) whilst, on

the other, they could offer an alternative way of exchange that maximises well-being within communities and the wider society (radical) - each of which requires a different role for government.

Despite the lack of a consensus in definition (or perhaps because of this) there has been significant promotion of 'social enterprise' by Governments (Teasdale, 2012b). Furthermore, intermediary organisations have inflated their own importance by talking up what social enterprise can do and their innovative capabilities (Floyd, 2013a). This has done the sector no favours. In the event of social enterprise being unable to fulfil these exaggerated claims, it is quite possible that the private sector will move into the vacuum created by failed contracts causing the reputation and credibility of social enterprise to be further dented.

\section{The evasion over making the social purpose and fundamental values explicit}

In the development of community and social enterprise there has been an explicit emphasis upon values. In 1997 a European funded project identified some of the key values and structures of social enterprise across Europe (Birkhölzer, 2009). This project 
identified 11 key values but did not suggest they all had to be adopted by all social enterprises, rather they were principles that added to our understanding about social enterprise.

In the 'radical' social enterprise one might expect a clearer emphasis on fundamental values such as tackling social injustice and promoting equity. In the founding of a social enterprise the social purpose and shared values are often the starting point but often due to external pressures and the need to maintain sustainability, they drift into becoming more like a 'reformist' social enterprises. When this happens these emphatic, fundamental beliefs are often replaced by more superficial values.

\section{Managing social enterprise - trials and tribulations}

It is not easy to manage a social enterprise - particularly a more 'radical' one. Without sufficient resources, it will struggle to be financially sustainable and at the same time provide social or community benefit. Given the 'pushes' and 'pulls' of the landscape outlined in the previous section, there are considerable issues facing individual social enterprise entities, including, but not limited to: maintenance of social purpose and financial survival; size; management tensions; and assessing impact of social change.

\section{(a) Maintaining social purpose and financial survival}

Social enterprises are expected to deliver public services or provide goods at a competitive price and have a social impact. Often social enterprises who start out with high aspirations to create social impact find the lack of resources make it impossible to attain in practice. This can be illustrated as follows.

For a private company to produce goods or provide a service in a traditional market economy it requires:

...raw materials + labour + equipment/premises + profit + marketing to secure the contract or sell the good...

A social enterprise is expected to produce some form of benefit or 'social profit', therefore the formula is:

...raw materials + labour + equipment/premises + profit + marketing to secure the contract or sell the good + social profit...

In a booming economy, it might be possible to do this and remain as a 'radical' social enterprise. But during a period of austerity when competition is fierce, there will be 
tensions between the main variables, namely, labour, profit and 'social profit'. Traditional profit can be pared down but a social enterprise would still need money to reinvest for expansion and to cover depreciation. Often there is pressure to reduce the 'social profit' and when this happens a social enterprise gravitates to becoming more like a 'reformist' social enterprise. Similarly, there may be pressures not to improve the conditions of the labour which causes social enterprises to resort to zero hours contracts and wage stagnation.

\section{(b) Size of social enterprise}

There is also an issue around size and the economies of scale within social enterprise (TechNet, 2009). A larger enterprise and one that by implication is perhaps not as rooted in a local community, is far more likely to win a contract, as proportionately its overheads are less. In the face of strong competition and the reduced economies of scale within larger organisations, a smaller social enterprise would have to squeeze social profit or labour or both in order to win contracts. Consistent with values and ideals, such as propounded in Schumacher's Small is Beautiful (Schumacher, 1973), in 'radical' social enterprises mutuality and trust are important between all stakeholder groups. These crucial elements are often dissipated in larger organisations. There is a balance required between decreasing economies of scale and strong relationship within a social enterprise.

\section{(c) Managing tensions}

Social enterprises have to manage a complicated array of factors and imbalances particularly if they are community-based which implies an extra need to be accountable to the local community; and particularly if they are taking more of a 'radical' approach. The CEST Transfer Project identified a number of tensions within social enterprise that have to be managed and summarised them in Table 1 (albeit some relate exclusively to community enterprise): 


\begin{tabular}{|c|c|c|}
\hline \multicolumn{3}{|c|}{$\begin{array}{l}\text { Some of the tensions that have to be managed within social and community } \\
\text { enterprises }\end{array}$} \\
\hline Managing the enterprise as a business & Vs. & $\begin{array}{l}\text { Running the enterprise as a means to } \\
\text { achieve social objectives }\end{array}$ \\
\hline $\begin{array}{l}\text { Stressing the underpinning } \\
\text { values of the social enterpr }\end{array}$ & Vs. & $\begin{array}{l}\text { Concentrating on achieving the } \\
\text { activities to an adequate degree }\end{array}$ \\
\hline $\begin{array}{l}\text { Having a mechanism to be accountable } \\
\text { to key stakeholders including the } \\
\text { community }\end{array}$ & Vs. & $\begin{array}{l}\text { Being able to be effective in making } \\
\text { decisions quickly and making them } \\
\text { clear }\end{array}$ \\
\hline $\begin{array}{l}\text { Re-investing any surplus in the social } \\
\text { enterprise to expand and develop }\end{array}$ & Vs. & $\begin{array}{l}\text { Using the surplus to support other, } \\
\text { wider work in the locality eg. } \\
\text { donations, etc. }\end{array}$ \\
\hline $\begin{array}{l}\text { Spending time managing the social } \\
\text { enterprise }\end{array}$ & Vs. & $\begin{array}{l}\text { me on local projects and } \\
\text { s that benefits the locality }\end{array}$ \\
\hline $\begin{array}{l}\text { Expansion of the social enterprise to } \\
\text { become bigger and changing the } \\
\text { original mission }\end{array}$ & Vs. & $\begin{array}{l}\text { Remaining small and concentrate on } \\
\text { providing services within the locality }\end{array}$ \\
\hline $\begin{array}{l}\text { Spending time raising funds and } \\
\text { accounting to funders and on social } \\
\text { accounting and similar }\end{array}$ & Vs. & $\begin{array}{l}\text { Spending time on delivering the core } \\
\text { work of the social enterprise }\end{array}$ \\
\hline $\begin{array}{l}\text { Recruiting people with a community } \\
\text { development background }\end{array}$ & Vs. & $\begin{array}{l}\text { Recruiting people with a business } \\
\text { background }\end{array}$ \\
\hline $\begin{array}{l}\text { Providing the staff with excellent } \\
\text { conditions and pay }\end{array}$ & Vs. & $\begin{array}{l}\text { Providing services to clients and } \\
\text { customers which are affordable }\end{array}$ \\
\hline $\begin{array}{l}\text { Deciding to keep staff and being } \\
\text { committed to the workforce }\end{array}$ & Vs. & $\begin{array}{l}\text { Making staff redundant in the event of } \\
\text { a decrease in the work }\end{array}$ \\
\hline
\end{tabular}

Table1: Some tensions that have to be managed within social and community enterprises

Decision-making in social enterprise is often made collectively and gaining consensus within and between the stakeholders, including different levels of staff. Inevitably this can make decision-making take longer.

Social enterprises would seem to depend much more on the goodwill and motivation of their staff and other stakeholders than traditional commercial enterprises as often they are less strong financially. The level of trust plays an important role and the relationship between the social enterprise and its workforce is often more 'organic', based upon trust, but crucial to its success (TechNet, 2009)

\section{(d) Assessing the performance and impact of social enterprise}

As a way of continuing to aspire to be a social enterprise, Pearce (2003) predicted an increasing focus on social enterprises being able to explain and account for their social 
purpose. If the social purpose of an organisation is central to the organisation then, he argued, that it is crucial that that social purpose should be explained and used as the barometer of whether or not the social enterprise is regarded as a 'success'.

Pearce (2003) describes in detail the process and benefits of 'social accounting and audit'. However, he could not have predicted the exponential growth and interest around 'social impact' over the last decade. Although social accounting in its current form has been around since the late 1980s (Pearce \& Kay, 2005, 2008) 'social return on investment' (SROI) has recently dominated this area of 'social impact measurement' (Arvidson, et al., 2013). This is partly because many still see social enterprise as 'reformist', where finance and the importance of using financial figures to explain social and community benefit is dominant.

More recently there are signs that social enterprises are beginning to understand that it is difficult and sometimes undesirable for their social and community impacts to be reduced to only a financial return on investment (Arvidson et al., 2013). Private businesses assess their success in terms of increased turnover, expanded staff numbers, more assets and their share of the market. Social enterprises should be different and examine the degree of positive social change that happens as a result of their activities. The social purpose should not be to maximise financial profit, but to maximise the 'social profit'. These measures are the indicators for a successful social enterprise and should be an integral part of the management and planning of a social enterprise.

\section{Re-imagining social enterprise}

The argument in the previous section would seem to say that establishing and maintaining a 'radical' social enterprise is just too difficult. This might suggest that a more 'reformist' approach is preferable. In this section, we argue that social enterprise can offer a more radical and alternative approach as a means of changing society and ultimately - contributing to individual and community well-being. We will commence, however, by touching upon the historical roots of social enterprise and then suggest a different conceptual framework and raise a number of implications that potentially arise as a result. 


\section{(a) The roots of social enterprise}

Social enterprise comes from a long history of organisations set up to tackle a socioeconomic problem, or to contribute to the common good, or both. Arguably it is important to recognise the origins of social and community enterprise to help understand what it has become and its future potential.

For much of his working life, Pearce was based in Scotland. In Scotland, communityowned businesses, building on experience of community co-operatives in the Highlands and the west coast of Ireland, have existed since the 1970s (Hayton, 2000; Pearce, 1993; Roy et al., 2015). They were set up, owned and managed by local people to create jobs and services for residents in hard-pressed communities. Much of Pearce's work is based on this historical perspective and, as he points out in Anytown, it is possible to recognise the same issues facing social enterprises today as those that were faced by community businesses 30 years ago (Pearce, 2003).

Roy et al (2015) outline the historical roots of social enterprise in Scotland, but the rise of social enterprise is an international phenomenon, and emerged from community owned enterprise and co-operatives across much of Europe. This international perspective is reflected not only in Pearce's work, but also more recently by the likes of Ridley-Duff \& Bull (2011).

\section{(b) Alternative conceptual framework}

In re-imagining social enterprise and asserting the principles and values that underpin a social enterprise - especially those with ambitions to take a more 'radical approach - it may be necessary to adopt a re-invigorated paradigm. Social enterprise can provide an alternative and fairer way of exchanging goods and services and at the same time have a social and community impact (Pearce, 1993). Social enterprise is not just a business with some social objectives, but rather a way in which people can work together in order to create well-being in terms of equality and fairness.

Traditionally, it has been widely regarded that social enterprises have a 'triple bottom line' of social, environmental and economic impacts. In re-imagining social enterprise, we suggest that social enterprise should be using economic activities as a means to an endthe end being working towards social, environmental and societal impacts. So not only 
impacting upon individuals and communities, but upon the relationships between them. These impacts are illustrated in Figure 2.

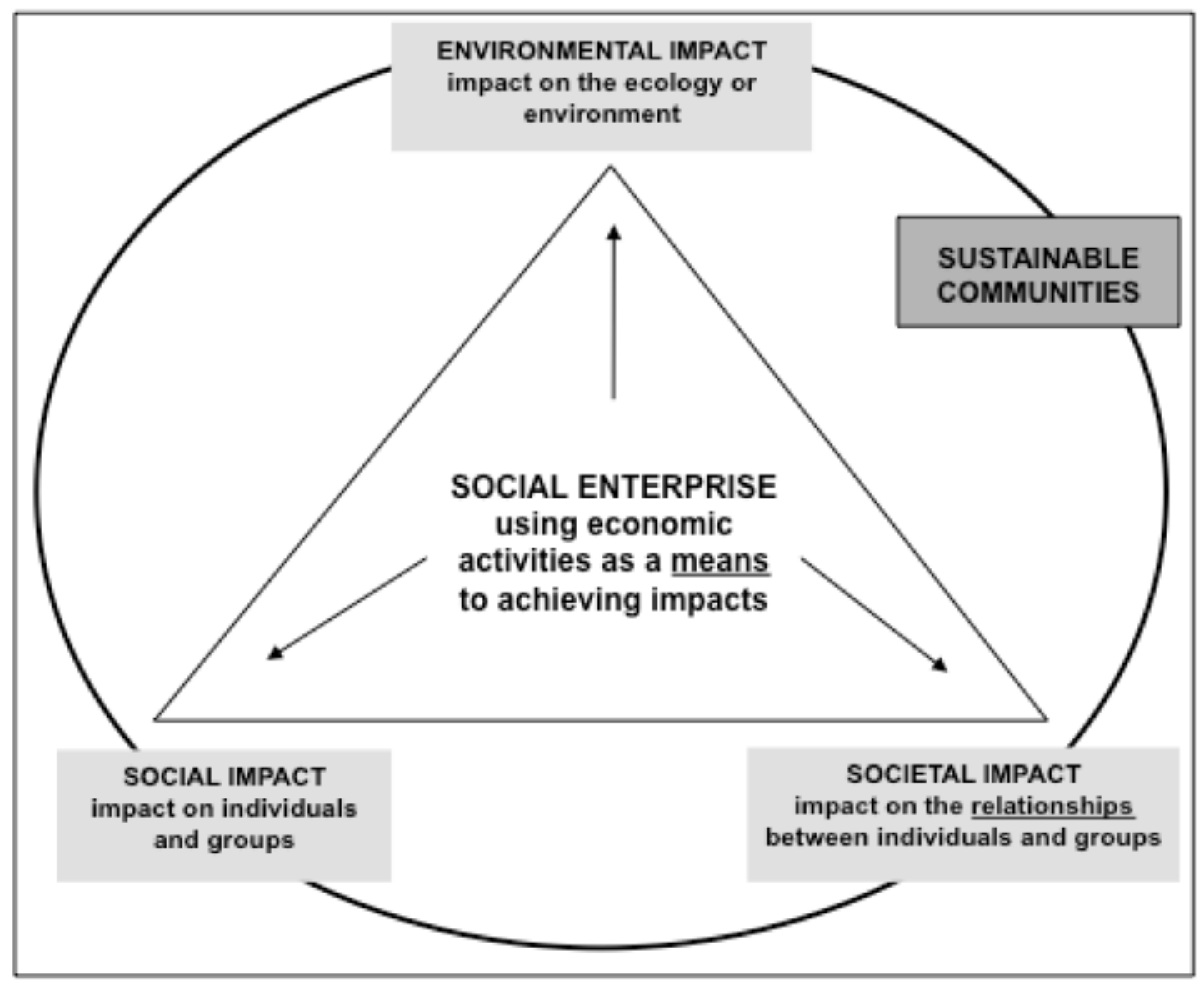

Figure 2: Impacts on sustainable communities

Rather than perceiving the economy as an 'impact', the use of economic activities is what a social enterprise does - a means. But this is different from the final ends, which are social, environmental or societal in nature. Thus, economic activities are a means to an end and not an end in itself. All organisations and people have an impact on the environment. At the very least, social enterprise can monitor that it does not have an adverse or negative affect on the environment. Social enterprise should impact on people and their livelihoods in a positive way, ensuring well-being and prosperity; where prosperity is more than money and distinct from wealth for its own sake. So as a society, we should prosper as the sum of all our activities, and not only for the prosperity of a few. We consider that the relationships between people and groups are largely influenced by, and indeed cannot be seen as separate from, the culture within a society: the way things 
are done, the rules and behaviours and the expectations of how things should be. All social enterprises operate in a societal context and should monitor their impact on the wider society in which it operates - its contribution to a culture that promotes fairness, equality and the 'common good'.

The point being made is that social enterprise provides an opportunity to change societal or cultural norms. Profit based economic enterprises have always had an impact on culture and indeed underpin it in profound ways: one only has to acknowledge the importance of competitiveness in society or a belief in the rightness of having winners and losers to know how important economic enterprises have been in promoting and sustaining such values. Social enterprises should challenge this cultural norm with an alternative way of operating.

In this re-imagining of social enterprise, there is an additional connection between the social enterprise's value base (or the way it 'does business') and its impacts. In an economy where 'values' become increasingly important social enterprise will benefit from being explicit about their values and how it is living up to them. This recognition of distinct shared ethical values - at least in theory - is what makes a social enterprise different from other forms of enterprise (Chell et al., 2014; Ridley-Duff, 2008)

The social enterprise sector is still small in scale, with marginal impact in an economic world driven by a capitalist mode of enterprise. Despite this, the more 'radical' social enterprises could, we argue, provide a means to support people to get out of poverty; as a way of opening up new, sometimes local, markets and jobs when more traditional enterprises would say no market existed; as a stop-gap measure in situations where traditional enterprises have abandoned activities; as a way of bringing into the labour force groups of people rejected by mainstream enterprises (people with disabilities, women, ethnic minorities); as an incubator for products and services that financial markets refused to invest in. Social enterprise could be a model of how things could be in relation to social, environmental and societal impacts: how they 'do' business and organise their internal relationships.

\section{(c) Implications from the conceptual framework}

If one accepts this paradigm for social enterprise, then a number of things fall into place. Firstly, social enterprise will not have to assume that adding to the economy is an end in 
itself. For example, it may provide jobs and employment, not just so people can spend more in the economy but, rather, to offer long term unemployed people, for example, employment in 'good work' which enhances their livelihoods thus addressing the disparities between the better off and the less well off. Secondly, social enterprises can put in place a set of values that define how they want to influence the way we live and work together as a society. Thirdly, it allows for a wider understanding of economic activities and for some social enterprises the adoption of ways to exchange goods and services that create prosperity and well-being without necessarily contributing to the financial economy e.g. volunteer labour, LETS (Local Exchange Trading Systems), box schemes, and so on. Fourthly, some social enterprises are beginning to challenge and redefine the nature of 'products' in a market society - so that we buy reused goods and exchange our material goods in different ways e.g. the Circular Economy. Lastly, in accepting that social enterprise can have an impact on society, the concept that we are not individual 'islands' needs to be re-emphasised. Rather we live and work within society and have an influence on that society and the relationships within it.

\section{(d) Alternative ways of exchanging goods and services}

Furthermore there are a number of other factors that can be introduced to ensure the survival and expansion of 'radical' social enterprises. How can the paradigm described above help social enterprises to become more successful?

The global economic system cannot be easily changed. There will likely still be all manner of inequalities and both absolute and relative poverty for the foreseeable future. But there is an argument to say that things can be changed at the 'edges' and that social enterprise can still be a vehicle to try and do this. Social enterprises that want to adhere to their principles could survive and indeed flourish in terms of social benefit if they adopt different ways of doing things. For example, they can: raise funds through a variety of sources to supplement earned income (e.g. donations or crowd funding); rely for periods of time on volunteer 'work' or sweat equity; develop and maintain links to a local community (this is often evident in increasing resilience in peripheral economies); use social capital as a resource and in a strategic way; use social marketing (meaning linking the producer more directly to the consumer e.g. box schemes, community-owned bakeries); and work in collaboration trying to substitute competition with co-operation thus sharing resources 
On a pragmatic front, many of these things are happening within social enterprises already, but they may be being 'kept under the radar' as some believe that they will not be regarded as a 'true' social enterprise if they resort to such actions. Perhaps what is required is a change in the 'milieu' and those actions that enable and encourage spin-off and additional social benefits would become more recognised and accepted. The social enterprises with a more 'radical' approach are currently in existence as community enterprises, community co-operatives and development trusts.

In the last couple of decades there has been a growing interest in the concept of social and solidarity economy (SSE), particularly in the Francophone world and across much of Latin America, to describe local economies based on mutuality and localism. Connected with these organisations are a variety of jumbled and associated terms such as: resilient economies to signify communities that can survive using alternative means such as volunteering; where livelihoods become to take on greater importance than 'jobs' that may be of variable quality and value; and where local resources and 'assets' are used to benefit a community of local residents. The SSE may yet play a significant role in the transition period that stresses the survival of localism, socially and economically, over a capitalist world economic order.

\section{Conclusion}

Our unashamedly polemical stance is predicated upon the fact that social enterprise is at an important juncture in its development. There is still no unassailable definition for social enterprise, which continues to cause debate and is often a distraction. The nature of social enterprise is, however, widely understood and falls into that odd category of things, that we all understand, but cannot precisely and accurately come up with a widely shared description. The social enterprise movement might split: at one extreme there will be businesses with strong social responsibility making as much profit as possible so that a portion of it can be funnelled into philanthropic ventures (reformist); and at the other extreme community-based social enterprises with adherence to sets of values and principles that ensure all that it does and how it does it leads to social or community benefit (radical).

In some ways this debate about social enterprise is really about what kind of a society we want to live in and how we interact and provide goods and services fairly and in a way 
that serves the interests of society as a whole. The argument implicit in much of this article is that the solution is perhaps 'local'.

We cannot immediately and fundamentally change the economic order but we can start independent initiatives that address needs of communities; initiatives in controlling our economic activity to evenly benefit the wider population. Certainly, private enterprise and the public sector play a part in this, and social enterprise is still part of the economy. But we have to retain and stress the original reasons why it is important. In re-imagining social enterprise there has to be re-imagining of the vision Pearce charts out in Anytown and Pearce concludes his book with a 'manifesto' for social enterprise along the following lines:

- Stress the shared social values

- Build a vision around mutual help and collaboration

- Celebrate what is different about social enterprises

- Agree and adopt a definition for social enterprise so we know what we are talking about

- Emphasise fair and democratic principles in social enterprise structure

- Ensure social enterprises are independent and not a phalange of the state

- Establish and develop financial institutions owned mutually across the sector

- Support each other and collaborate rather than compete with each other

- Adopt a form of regular social accounting with credible reporting systems

- Think global and act local, thus changing society

It would appear that Pearce's summary 'manifesto' in the bullet points above is just as relevant today as it was when the book was written. Although Pearce wrote Social Enterprise in Anytown in 2003, the agenda for change has not changed; if anything, the social need has become greater. The above 'manifesto' presents a challenge for the sector and associated policy makers to devise a more supportive framework for social enterprise. This is in terms of defining social enterprise and thus the wider sector, offering appropriate finance to encourage its spread, and supporting social enterprise to explain and provide evidence of its performance and impact. However, throughout his working life Pearce was wary of government, but without its support, social enterprise will, in all likelihood, remain marginal. On the other hand, with government support social enterprise may lose its 'essence' as an alternative way of providing goods and service. Therein lies the dilemma. 
Despite all this, one cannot help but wonder what Pearce would make of the current situation. He would likely be fascinated at the recent developments, but at the same time worried that we seem to be losing the 'essence' of social enterprise: to apply economic activities to address real social needs, in a fair and socially just way.

\section{Acknowledgements}

This study was supported with the financial assistance of the Medical Research Council and Economic and Social Research Council, grant ref: MR/L0032827/1 for a programme entitled 'Developing Methods to Evidence 'Social Enterprise as a Public Health Intervention'. 


\section{References}

Anheier, H. K., \& Toepler, S. (2009). International Encyclopedia of Civil Society. New York: Springer.

Arvidson, M., Lyon, F., McKay, S., \& Moro, D. (2013). Valuing the Social? The Nature and Controversies of Measuring Social Return on Investment (SROI). Voluntary Sector Review, 4(1), 3-18.

BALTA. (2007). What Is The Social Economy? Retrieved October 17, 2014, from http://www.socialeconomy-bcalberta.ca/social-economy/

Birkhölzer, K. (2009). The Role of Social Enterprise in Local Economic Development. In The Second EMES International Conference on Social Enterprise. Trento, Italy: EMES International Research Network. Retrieved from http://euricse.eu/sites/default/files/db_uploads/documents/1254754553_n17 $0 . p d f$

Chell, E., Spence, L. J., Perrini, F., \& Harris, J. D. (2014). Social Entrepreneurship and Business Ethics: Does Social Equal Ethical? Journal of Business Ethics. http://doi.org/10.1007/s10551-014-2439-6

Dey, P., \& Teasdale, S. (2015). The Tactical Mimicry of Social Enterprise Strategies: Acting "As If" in the Everyday Life of Third Sector Organizations. Organization, 120. http://doi.org/10.1177/1350508415570689

Eikenberry, A. M., \& Kluver, J. D. (2004). The Marketization of the Nonprofit Sector: Civil Society at Risk? Public Administration Review, 64(2), 132-140.

Fitzhugh, H., \& Stevenson, N. (2015). Inside Social Enterprise: Looking to the Future. Bristol: Policy Press. 
Floyd, D. (2013a). Measurement and Scale: The Social Entrepreneur 16 Years On. Retrieved from http://beanbagsandbullsh1t.com/2013/09/24/measurementand-scale-the-social-entrepreneur-16-years-on/

Floyd, D. (2013b, August 13). Are Social Enterprises Fit for the Future of Public Services? The Guardian Social Enterprise Network. Retrieved from http://www.theguardian.com/social-enterprise-network/2013/aug/13/socialenterprises-public-services-spin-outs

Grey, C., \& Mitev, N. (1995). Management Education: A Polemic. Management Learning, 26(1), 73-90.

Hassan, G. (2015, November 30). The Tories Are Shrinking the State While Labour Go Back to the 1980s. Retrieved from http://www.gerryhassan.com/blog/thetories-are-shrinking-the-state-while-labour-go-back-to-the-1980s/

Hayton, K. (2000). Scottish Community Business: An Idea That Has Had Its Day? Policy and Politics, 28(2), 193-206. http://doi.org/10.1332/0305573002500910

Kay, A. (2003). Social Capital in Building the Social Economy. In J. Pearce, Social Enterprise in Anytown (pp. 73-82). London: Calouste Gulbenkian Foundation.

Lewis, M., \& Swinney, D. (2008). Social Economy and Solidarity Economy: Transformative Concepts for Unprecedented Times? Making Waves, 18(4), 9-15. McHugh, N., Sinclair, S., Roy, M. J., Huckfield, L., \& Donaldson, C. (2013). Social Impact Bonds: A Wolf in Sheep's Clothing? Journal of Poverty and Social Justice, 21(3), 247-257.

McKee, M. (2011). Circle Health Is Not Like the John Lewis Partnership. BMJ, 343(dec13 1), d7897. 
Nicholls, A. (2010). The Legitimacy of Social Entrepreneurship: Reflexive Isomorphism in a Pre-Paradigmatic Field. Entrepreneurship Theory and Practice, 34(4), 611633.

Pearce, J. (1993). At the Heart of the Community Economy: Community Enterprise in a Changing World. London: Calouste Gulbenkian Foundation.

Pearce, J. (2003). Social Enterprise in Anytown. London: Calouste Gulbenkian Foundation.

Pearce, J., \& Kay, A. (2005). Social Accounting and Audit: The Manual. Edinburgh: CBS Network.

Pearce, J., \& Kay, A. (2008). Really Telling Accounts! Exeter: Social Audit Network. Polanyi, K. (1944). The Great Transformation: The Political and Economic Origins of Our Time (Second Beacon Paperback Edition Published in 2001). Boston, MA: Beacon Press.

Polanyi, K. (1957). The Economy as Instituted Process. In K. Polanyi, C. M. Arensberg, \& H. W. Pearson (Eds.), Trade and Market in the Early Empires: Economies in History and Theory (pp. 243-269). Glencoe, IL: Free Press.

Ridley-Duff, R. (2008). Social Enterprise as a Socially Rational Business. International Journal of Entrepreneurial Behaviour \& Research, 14(5), 291-312.

Ridley-Duff, R., \& Bull, M. (2011). Understanding Social Enterprise: Theory \& Practice. London: SAGE.

RIPESS. (2015). Global Vision for a Social Solidarity Economy: Convergences and Differences in Concepts, Definitions and Frameworks. RIPESS - International Network for the Promotion of Social Solidarity Economy. Retrieved from http://www.ripess.org/wp-content/uploads/2015/02/RIPESS_GlobalVision_EN.pdf 
Roy, M. J., \& Hackett, M. T. (2016). Polanyi's “Substantive Approach" to the Economy in Action? Conceptualising Social Enterprise as a Public Health "Intervention." Review of Social Economy, 1-23. http://doi.org/10.1080/00346764.2016.1171383

Roy, M. J., McHugh, N., Huckfield, L., Kay, A., \& Donaldson, C. (2015). “The Most Supportive Environment in the World"? Tracing the Development of an Institutional “Ecosystem” for Social Enterprise. Voluntas: International Journal of Voluntary and Nonprofit Organizations, 26(3), 777-800.

Schumacher, E. F. (1973). Small Is Beautiful: A Study of Economics as if People Mattered. London: Blond \& Briggs.

Teasdale, S. (2012a). Negotiating Tensions: How Do Social Enterprises in the Homelessness Field Balance Social and Commercial Considerations? Housing Studies, 27(4), 514-532.

Teasdale, S. (2012b). What's in a Name? Making Sense of Social Enterprise Discourses. Public Policy and Administration, 27(2), 99-119.

Teasdale, S., Lyon, F., \& Baldock, R. (2013). Playing with Numbers: A Methodological Critique of the Social Enterprise Growth Myth. Journal of Social Entrepreneurship, $4(2), 113-131$.

TechNet. (2009). CEST - Training for the Social Economy. Retrieved November 30, 2015, from http://www.cest-transfer.de/index.html 